\title{
Is Crime in Turkey Economically Rational?
}

\author{
JØrgen T. LAURIDSEN ${ }^{\text {a }}$, FATMA ZEREN ${ }^{\text {b }}$, AYŞE ARI ${ }^{c}$ \\ a Centre of Health Economics Research (COHERE), University of Southern Denmark, Campusvej 55, \\ DK-5230 Odense M, Denmark.E-mail: jt1@sam.sdu.dk \\ b Inonu University, Faculty of Administrative and Economy, 44280, Malatya, Turkey. E- \\ mail: fatma.zeren@inonu.edu.tr \\ c Nigde University, Faculty of Economics and Administrative Sciences, 51240, Nigde, Turkey. E- \\ mail: ayseari187@yahoo.com
}

\begin{abstract}
The study investigates whether crime in Turkey is governed by economic rationality. An economic model of rational behaviour claims that the propensity to commit criminal activities is negatively related to risk of deterrence. Potential presence of higher risk profiles for certain population segments is investigated. Panel data aggregated to sub-regional levels and observed annually for the years 2008 to 2010 are applied. Controls for endogeneity among criminal activity level and risk of deterrence, intra-regional correlation, inter-temporal heterogeneity and spatial spillover are exerted. A positive effect of risk of deterrence on criminal activity is found which conflicts with the hypothesised economic rationality. Certain population segments are identified as obvious target groups for regional policy initiatives aiming to reduce criminal activities. These are in particular unemployed and males. On the other hand, educational attainment, poverty and youngsters are less obvious target groups, while the potential relationship between population density and crime is ambiguous. Finally, spatial spillover patters related to criminal activities seem to be highly relevant, thus implying that while initiatives toward criminal activities may well be formed at the regional level, coordination across regions might obviously be called for.
\end{abstract}

Keywords: Crime, Risk Of Deterrence, Turkey, Panel Data, Spatial Spillover.

\section{¿Es económicamente racional el crimen en Turquía? RESUMEN}

Este trabajo analiza si el crimen en Turquía se puede explicar por criterios de racionalidad económica. La aproximación económica tradicional sostiene que la propensión a cometer actividades delictivas está negativamente relacionada con la capacidad de disuasión. En el trabajo se investiga la existencia de perfiles de riesgo más altos para ciertos segmentos de la población. Utilizamos datos panel con frecuencia anual y agregados a nivel subregional y durante los años 2008 a 2010. En el modelo que se estima se controla la endogeneidad entre el nivel de actividad criminal y la capacidad de disuasión, la correlación intra-regional, la heterogeneidad inter-temporal y los efectos spillover espaciales. En los resultados encontramos que la capacidad disuasión tiene un efecto positivo sobre la actividad criminal lo que entra en conflicto con la hipótesis de racionalidad económica. Identificamos ciertos segmentos de población como objetivos obvios para poner en marcha iniciativas de política regional que quieran reducir las actividades criminales. Estos son, en particular, varones y desempleados. Por otra parte, los resultados educativos, la pobreza y los jóvenes constituyen objetivos menos obvios, mientras que la hipotética relación entre densidad de población y crimen es ambigua. Por último, los patrones de contagio espaciales asociados a actividades delictivas son muy relevante, lo que implica que las iniciativas para contener las actividades criminales deben adoptarse en el ámbito regional y que la coordinación entre regiones es necesaria.

Palabras clave: Crimen, capacidad de disuasión, Turquía, datos panel, spillovers espaciales.

JEL Classification: K42, C21, C23

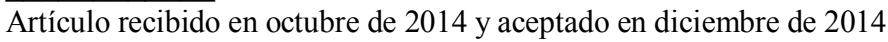

Artículo disponible en versión electrónica en la página www.revista-eea.net, ref. ə-33108 


\section{INTRODUCTION}

The investigation of determinants of crime is important not only because of the serious nature of the problem in itself but also in terms of public policy implications (income, immigration, employment, etc.). The study of Becker (1968) represents a starting point of the economics of crime. His paper explains how changes in the probability and severity of punishment can alter the individual's decision to commit crime. Later, Ehrlich (1973) extended the Becker model by considering how individuals divide their time between illegal and legal activities. If legal income opportunities are scarce relative to the potential benefits of crime, people allocate more time to illegal activities and crime is likely to occur. Since then, an extensive empirical literature has attempted to test the central results of the Becker-Ehrlich model for a number of countries. These studies has focused on Canada (Avio and Clarke, 1976), Finland (Wahlroos, 1981), UK (Car-Hill and Stern, 1973; Wolpin, 1978), Australia (Whithers, 1984; Bodman and Maultby, 1999), US (Trumbull, 1989; Cornwell and Trumbull, 1994; Baltagi, 2006), New Zealand (Small and Lewis, 1996; Papps and Winkelman, 1998), Italy (Marselli and Vannini, 1997; Buonanno and Leonida, 2006), Sweden (Sandelin and Skogh, 1986), Germany (Entorf and Spengler, 2000), Poland (Lauridsen, 2010), the Baltic countries (Lauridsen, 2009) and Norway (Aasness et al., 1994).

This formal literature estimates the supply of crime employing different types of data set (aggregate data, cross-sectional data and panel data) where the crime rate is related to some deterrence as well as socio-economic and demographic variables. So far, the empirical literature has provided mixed evidence; see Eide (2000) for a review. More recently, some papers have addressed the importance of controlling for other socio-economic factors in the criminal behaviour, such as drug abuse (Entorf and Winker, 2001, 2008), guns possession (Miron, 2001), juvenile delinquency (Mocan and Rees, 1999), income inequality (Fajnzylber et al., 2002), immigration (Butcher and Piehl, 1998), social capital (Dilulio, 1996), minimum wages (Hansen and Machin, 2003) and home ownership (Lauridsen et al., 2013).

Several behavioral theories contribute to explain the relationships between crime and economic conditions and the causalities behind (Croall, 1998; Britt and Chester, 1994). Motivation theory argues that individuals are prone to committing crimes during recession because income levels are reduced. Crime rates increase during economic depression because consumption is reduced and unemployment increases. Thus, motivation theory argues that there is a positive relationship between adverse economic conditions and crime. If an unemployed person believes that illicit money to be gained by criminal offense is worth the criminal liability to be imposed after breaking law, the person will be more likely prone to criminal activities. Furthermore, opportunity theory argues that 
increased income and number of goods in circulation during period of economic growth creates the opportunity of committing a crime. The number of goods in circulation increases in parallel to the income increases. This increases the opportunity of committing a crime. Opposed to the motivation theory, the opportunity theory argues that crime rates will be lower in case of adverse economic conditions. People who lose their jobs during recession are forced to spend most of their times at home, whereby the possibility of being involved in a crime outside the house or being the victim of a crime will be reduced. These two theories reveal the complexity of the relationship between crime and economy. However, the studies on the context of economic structure and crime association generally confirm that unemployment and poverty increase the crime rates.

Problems related to criminal activity are highly relevant from a regional policy perspective. Criminal activity is commonly seen to be a phenomenon that varies strongly across regions of any country. Furthermore, criminal activity is something that can be learned through a social interaction process. It is very likely that criminality in one region can affect criminality in neighbour regions. This diffusion process of criminality implies that a spatial dependence or a spatial spillover exists among cities or areas. Such effects have been identified by Cohen and Tita (1999), Baller et al. (2001), Messner and Anselin (2002), Buttner and Spengler (2003), and Puech (2004). Conceptually, such spatial spillover may assume two potential forms. One form is an endogenous spillover, i.e. a high criminal activity in a certain area in itself leads to high criminal activity in neighbour regions. Another form is exogenous spillover which is related to spatial clustering of determinants of crime. Thus, if there is a high concentration of risky population segments in a certain area, then the criminal activity will be high, not only in this region but also in neighbour regions.

The present study examines the determinants of crime rates in Turkey based on data aggregated to sub-regional levels during the period 2008 to 2010. Data were collected from the Turkish Statistical Institute. Certainly, data availability at the regional level puts some restrictions on the set of determinants which could be included. The study thus includes the key variable risk of deterrence. Further, some variables are included to control for varying risk profiles across certain population segments. These are poverty level, education, young people, males, population density, and unemployment.

While the set of variables extracted is somewhat narrow, it corresponds well to suggestions of existing evidence. The effect of risk of deterrence is well documented for US (Levitt, 1996; Levitt, 1997, Levit, 1998; Corman and Mocan, 2000) and Western Europe (Edmark, 2005; Entorf and Spengler, 2000; Buonnano et al., 2006). However, the causal relationship among deterrence and crime rates is ambiguous in an aggregate setting. Obviously, a high deterrence rate of a region reduces the crime rate of the region, as the opportunity cost of 
committing crime goes up. On the other hand, it may well be the case that a high crime rate in a region stimulates policy initiatives to raise the deterrence rate.

Wealth is identified as another key determinant, however, with an ambiguously signed effect. One argument is that high incomes lead to higher opportunities of people to engage in legal activities. On the other hand, high incomes may serve as a proxy for illegal opportunities, as wealthy areas may be more attractive for criminals (Ehrlich, 1973; Entorf and Spengler, 2000). The unemployment rate is a central part of models of criminal activity since Becker (1968) and applies as a measure of lack of social capital and legal income opportunities. Education may furthermore be an important determinant of criminal activity. Specifically, higher educational attainment increases the opportunity cost of crime, as the expected loss from deterrence becomes higher. Recent research tends to support that education is negatively related to crime (Buonnano et al., 2006). Gender is known to exert an influence. Males, in particular young males, are known to possess a higher risk profile (Witte, 2002), and young people might in general have a lower opportunity cost of committing crime. Urban areas with high population densities are furthermore commonly seen to have higher crime rates than rural areas, even after controlling for socioeconomic characteristics of the areas.

From a regional policy perspective, these selected determinants are highly relevant, as most of them may be -more or less- affected by regional policy initiatives. Such policy initiatives may readily aim to reduce unemployment, increase income or stimulate educational attainment. Other initiatives or interventions may be targeted toward risky population segments, for example information campaigns directed toward young people, initiatives to stimulate the integration of immigrants etc.

Pooled data are analysed in order to allow for more variability and to improve efficiency of estimation. Thus, a Seemingly Unrelated Regression approach is called for in order to account for intra-regional heterogeneity and inter-temporal correlation. Further, as data are observed at sub-regional levels, the potential presence of spatial spillover as discussed above has to be controlled for. Finally, the above mentioned potential endogeneity among the risk of deterrence and crime rates needs attention. The study aims for doing this by applying an instrumental variable estimation.

The outline of the study is as follows. Next to the above introduction of problems related to investigation of criminal activity and its determinants, Section 2 discusses the socio-economic structure underlying crime rates in Turkey, followed by an outline in Section 3 of the methodological approaches of the study. Section 4 briefly presents the data to be applied for the study. After this, 
empirical results are presented and discussed in Section 5. Finally, Section 6 rounds off by extracting the essential conclusions of the study.

\section{SOCIO-ECONOMIC STRUCTURE AND CRIME RATES IN TURKEY}

Turkey experienced a drastic increase of crime rates recently, especially in 2006 and following years. As seen from the example given on Table 1, there were 55.966 criminals in the prisons in 2005 whereas the number of criminals increased by $26 \%$ in 2006 and reach up to 70524 people and the total number of criminals was increased by $28 \%$ in 2007, in comparison to the numbers of 2006, and reached up to 90732 people. The crime rates continued to increase in 2008 and have been increasing since then but the increase rate in question is at lower ratios. From 1997 to 2011, the number of total criminals increased by 110 $\%$. However, the total crime rate decreased in 2000, 2004 and 2005.

Table 1

Prison Population in Turkey

\begin{tabular}{|c|c|c|}
\hline Years & Total & Increase \\
\hline 1997 & 60843 & NA \\
\hline 1998 & 66096 & 0.086 \\
\hline 1999 & 67676 & 0.024 \\
\hline 2000 & 50628 & -0.252 \\
\hline 2001 & 55804 & 0.102 \\
\hline 2002 & 59512 & 0.066 \\
\hline 2003 & 63796 & 0.072 \\
\hline 2004 & 58016 & -0.091 \\
\hline 2005 & 55966 & -0.035 \\
\hline 2006 & 70524 & 0.260 \\
\hline 2007 & 90732 & 0.287 \\
\hline 2008 & 103435 & 0.140 \\
\hline 2009 & 115920 & 0.121 \\
\hline 2010 & 120194 & 0.037 \\
\hline 2011 & 128253 & 0.067 \\
\hline
\end{tabular}

Source: Turkish Statistical Institute.

The number of criminals to total population ratio in Turkey stayed within a range of 0.06 to 0.02 from 2001 until 2010. Although it is generally observed that the number of criminals in the total population has being increasing year by year, the ratio in 2006, 2007 and 2008 was at a level of 0.014. As seen in Table 2, when compared to some European countries, the number of criminals to the total population ratio is less in Turkey. Belgium has the highest ratio among all the countries indicated on Table 2 with a rate of 0.09. Denmark, England and Switzerland can be listed as other countries having a higher criminal/population ratio. In Greece, Hungary, Czech Republic and Portugal, the number of criminals/population ratio is relatively lower and close to each other. 
Table 2

Ratio of crime population to total population

\begin{tabular}{|l|c|c|c|c|c|c|c|c|c|c|c|c|}
\hline & Belgium & Denmark & Greece & Italy & Luxembourg & Hungary & UK & Germany & Switzerland & $\begin{array}{c}\text { Czech } \\
\text { Rep. }\end{array}$ & Portugal & Turkey \\
\hline 2001 & 0.092 & 0.088 & 0.040 & 0.038 & 0.051 & 0.046 & 0.093 & 0.077 & 0.044 & 0.035 & 0.036 & 0.006 \\
\hline 2002 & 0.096 & 0.091 & 0.040 & 0.039 & 0.058 & 0.041 & 0.101 & 0.079 & 0.049 & 0.036 & 0.038 & 0.007 \\
\hline 2003 & 0.095 & 0.090 & 0.040 & 0.043 & 0.058 & 0.041 & 0.101 & 0.080 & 0.052 & 0.035 & 0.040 & 0.007 \\
\hline 2004 & 0.095 & 0.088 & 0.037 & 0.042 & 0.059 & 0.041 & 0.094 & 0.080 & 0.053 & 0.034 & 0.040 & 0.008 \\
\hline 2005 & 0.094 & 0.080 & 0.041 & 0.044 & 0.054 & 0.043 & 0.092 & 0.078 & 0.047 & 0.034 & 0.037 & 0.010 \\
\hline 2006 & 0.095 & 0.078 & 0.042 & 0.047 & 0.055 & 0.042 & 0.090 & 0.077 & 0.045 & 0.033 & 0.038 & 0.014 \\
\hline 2007 & 0.096 & 0.082 & 0.038 & 0.049 & 0.059 & 0.042 & 0.081 & 0.076 & 0.043 & 0.035 & 0.038 & 0.014 \\
\hline 2008 & 0.095 & 0.087 & 0.037 & 0.045 & 0.058 & 0.041 & 0.077 & 0.074 & 0.042 & 0.033 & 0.041 & 0.014 \\
\hline 2009 & 0.097 & 0.089 & 0.034 & 0.044 & 0.065 & 0.039 & 0.070 & 0.074 & 0.087 & 0.032 & 0.040 & 0.018 \\
\hline 2010 & 0.096 & 0.085 & 0.030 & 0.043 & 0.060 & 0.045 & 0.067 & 0.073 & 0.084 & 0.030 & 0.040 & 0.021 \\
\hline
\end{tabular}

Source: Eurostat and World Bank.

Unemployment, poverty, population growth and urbanization might have impact on the crime rates in Turkey. On the other hand, although poverty is considered to be an important factor, it is a well-known fact that well-educated and wealthy people are involved in illegal activities. Besides, these are more organized groups. There are also crimes committed under the cover of the elite class.

Regardless of the national (2000-2001) and international (1997 and 2008) depressions suffered recently, Turkey has achieved a significant momentum in terms of economic growth. For example, GDP growth rate was $9.3 \%$ in 2004 and $8.7 \%$ in 2011 . However, the income inequality and regional differences in the level of development are material issues in the country. Thus, people emigrate from rural areas to metropolitans. People immigrating to the metropolitans cannot find jobs because of rapid population increases in these cities. Some work for shadow sectors. Besides, people feel estranged from the urban culture and have difficulties adapting to the city life. Individuals might also suffer from physiological issues because of such problems and these issues pave the way for illegal activities. Money has become more and more important factor in Turkey because of income inequality and the society started to consider having great fortune as the key of earning respect, rather than being knowledge, educated.

Turkey also suffers from a very high level of poverty and this ratio cannot be reduced despite the economic growth. For example, the poverty rates in 2007, $2008,2009,2010$ and 2011 were respectively $22.8 \%, 23.7 \%, 23.8 \%, 23.5 \%$ and $22.6 \%$. The unemployment rates in 1985, 1995, 1997, 2002, 2005, 2009 and 2011 where respectively $11.1 \%, 7.5 \%, 6.8 \%, 10.3 \%, 10.6 \%, 14 \%$ and $9.8 \%$. It is expected that unemployment rates, which are generally at higher levels, will be a material determinative of crime rates. Having a good job does not only mean earning income but also ensuring peaceful and comfortable lives of families and facilitating achieving goals and desires in life. Thus, losing 
one's job might have economic, social and physiological impacts on the individual and the individual might be prone to criminal activities. Moreover, we might say that the rapid population growth in Turkey increase unemployment and thus increase the likelihood of being involved in criminal activities. For example, population density numbers in Turkey were 78.4 people, 82.08 people, 88.02 people and 94.92 people, respectively in 1997, 2000, 2005 and 2011. Rapid population growth prevents individuals from receiving higher shares of welfare. Also, this increases the needs of housing, healthcare, education and infrastructure.

Turkish government tries to prevent crime. For example, the number of police officers is increased for the purpose of preventing crimes by increasing the possibility of being caught. Besides, reduced sentences offered for honor killings are cancelled. Generally, the sentences are aggravated and there have been legal arrangements for eliminating the conflicts or deficits related to the laws. However, there is a long way to go in terms of proceedings and sentences. For example, the recent repentance laws offering stay of execution or release on probation, excluding crimes against the state, were enacted in 2000 and 2002. Although this Act was available for crimes committed before the date of April 23, 1999, the annulment decision announced by the Supreme Courts expanded the scope of this Act and accordingly, lawsuits filed against 4 thousand 715 people were postponed in 2005. As a result, approximately 45 thousand people got out of jail. It is known that the governments have been enacting a repentance law every 6.5 years, in average, since the proclamation of the republic. This fact clears away the belief that crime will be punished and thus theory of criminal deterrence is impaired.

\section{METHODOLOGY}

The point of departure is a linear regression model defined for each year for the $N=81$ sub-regions by

$$
y_{t}=X_{t} \beta+v_{t}, \quad v_{t} \sim N\left(0, \sigma^{2} I\right)
$$

where $X_{t}$ is an $N$ by $K$ dimensional matrix of $K$ explanatory variables, $y_{t}$ an $N$ dimensional vector of endogenous observations, and $\beta$ a $K$ dimensional coefficient vector. While pooled data for $T=3$ years are applied, the residuals between years are correlated, and the variances within each year will vary across years, i.e. between any two years, the residual covariance reads as

$$
E\left(v_{t}{ }^{\prime} v_{s}\right)=\sigma_{t s}^{2} \quad t, s=1, . ., T
$$

To obtain efficient estimates of $\beta$, we apply Feasible Generalised Least Squares (F-GLS) estimation to obtain the Zellner (1962) Seemingly Unrelated 
Regression (SUR) estimates for $\beta$.

As the model is estimated using sub-regional data, spatial dependencies between the sub-regions have to be taken into account. It is intuitively clear that crime is not restricted to realise itself within a single sub-region, but rather flows over the sub-regional borderlines. Operationally the crime rate $\left(y_{t}\right)$ may not only be determined by the explanatory variables in the sub-region itself $\left(X_{t}\right)$, but also by values of $X_{t}$ in the surrounding sub-regions, i.e. exogenous spatial spillover may be in play. Furthermore, if the criminal activity in the surrounding sub-regions is high, this activity may spill over and induce criminal activities in the sub-region in question, i.e. endogenous spillover is readily expected. Alike any other omission of relevant variables, ignorance of spatial spillover may bias the results obtained (Anselin, 1988). Operationally, spatial spillover may conveniently be specified as part of the residuals thus obtaining the spatially autocorrelated (SAC) specification (Anselin, 1988)

$$
y_{t}=X_{t} \beta+\varepsilon_{t}, \varepsilon_{t}=\lambda \varepsilon_{t}^{W}+v_{t}
$$

where $\lambda$ is a parameter specifying the magnitude of spillover, formally restricted to the interval between $(-1)$ and $(+1)$, but for most practical purposes restricted to be non-negative, while $\varepsilon_{t}^{W}$ denotes the average of $\varepsilon_{t}$ in the neighbouring sub-regions. Thus, the spatial contiguity matrix $W$ to be applied is the row standardised version of a binary matrix, where $W_{i j}$ assumes the values 1 if the two regions are neighbours (i.e. have a borderline in common) and 0 otherwise. Combining the features of the SUR specification (1)-(2) with the SAC specification (3) leads to an integrated specification conveniently denoted the SAC-SUR.

In the specification (3), the parameters $\beta$ and $\lambda$ are assumed to be constant across years. This appears satisfying for the present study, given the short time span of three years. For other cases with longer time spans, it might be relevant to generalise the specification by allowing $\beta$ and $\lambda$ to vary across years; see Mur et al. (2010).

Next, potential endogeneity among crime rate and risk of deterrence has to be accounted for. This is done by applying a two-stage least squares instrumentalisation. Specifically, the risk of deterrence is in a first step regressed on the lagged values of crime rates and predicted values of risk of deterrence obtained. In the second step, the above estimations are performed, replacing risk of deterrence with these predicted values.

In order to evaluate the different models against each other, Likelihood Ratio (LR) tests will be utilised wherever possible, i.e. for SUR versus OLS and for 
SAC-SUR versus SUR. While the former of these LR tests serves as a test for intertemporal homogeneity of the model (similar to the test suggested by Breusch and Pagan, 1980), the latter serves as a test for spatial spillover (similar to the spatiotemporal Moran I test suggested by López et al., 2011). Given that the instrumentalised SAC-SUR does not nest any of the former specifications and thus not facilitates LR tests, we further report the estimated Log Likelihood (LogL) and Akaike's Information Criterion (AIC) values, which may serve as indicators for the relative performances of the alternative models.

\section{DATA}

Data on crime rates and the explanatory variables were obtained at sub-regional level. Data were available for the years 2008 to 2010. Table 3 provides full definitions of variables, together with descriptive statistics. The indicators for the region being a neighbour to Georgia, Armenia etc. were included in order to account for potential cross-border spillover of criminal activities between these countries and Turkey; such spillover is expected to be relatively more predominant for regions on the borderline in question.

Table 3

Definition of variables and descriptive statistics

\begin{tabular}{|l|l|c|c|}
\hline \multicolumn{1}{|c|}{ Variable } & \multicolumn{1}{c|}{ Definition } & Mean & $\begin{array}{c}\text { Standard } \\
\text { deviation }\end{array}$ \\
\hline Crime rate & $\begin{array}{l}\text { New cases brought to the Chief Public Prosecutors' Office per } \\
10,000 \text { inhabitants }\end{array}$ & 392.02 & 92.71 \\
\hline Risk of deterrence & Number of convicts received into prison per 10,000 inhabitants & 10.55 & 5.32 \\
\hline $\begin{array}{l}\text { Predicted risk of } \\
\text { deterrence }\end{array}$ & Risk of deterrence, predicted from previous year's crime rate & 10.55 & 3.33 \\
\hline Poverty & Percentage of population below poverty rate (rate=60 percent) & 19.99 & 1.90 \\
\hline Education & Number of graduates in higher education per 10,000 inhabitants & 72.42 & 196.06 \\
\hline Percentage 20-29 & Percentage of 20-29 year old & 17.27 & 1.98 \\
\hline Percentage males & Percentage of males & 50.41 & 0.01 \\
\hline Population Density & Number of inhabitants per square kilometre & 112.90 & 270.12 \\
\hline Unemployment & Unemployment rate & 11.05 & 4.13 \\
\hline Georgia & Indicator for region being neighbour to Georgia & 0.04 & 0.19 \\
\hline Armenia & Indicator for region being neighbour to Armenia & 0.02 & 0.16 \\
\hline Iran & Indicator for region being neighbour to Iran & 0.05 & 0.22 \\
\hline Iraq & Indicator for region being neighbour to Iraq & 0.02 & 0.16 \\
\hline Syria & Indicator for region being neighbour to Syria & 0.07 & 0.26 \\
\hline Greece & Indicator for region being neighbour to Greece & 0.01 & 0.11 \\
\hline Bulgaria & Indicator for region being neighbour to Bulgaria & 0.02 & 0.16 \\
\hline Regional level & 81 sub-regions & & \\
\hline
\end{tabular}

Source: Turkish Statistical Institute - Regional Statistics.

Table 4 provides descriptive statistics by year for those variables that varies across year, together with the annual Moran I statistics for crime rate. Although some variation across years is indicated, it is seen that the variables are compa- 
rable across years, and that the spatial dependence of the crime rates is persistently high throughout.

Table 4

Means of variables and Moran I statistic for crime rate by year

\begin{tabular}{|c|c|c|c|}
\hline Variable & $\mathbf{2 0 0 8}$ & $\mathbf{2 0 0 9}$ & $\mathbf{2 0 1 0}$ \\
\hline Crime rate & $355.70(91.47)$ & $396.21(91.33)$ & $424.14(83.04)$ \\
\hline Risk of deterrence & $10.27(4.24)$ & $9.87(5.38)$ & $11.52(6.08)$ \\
\hline Poverty & $19.71(2.54)$ & $19.98(1.69)$ & $20.27(1.19)$ \\
\hline Education & $65.02(156.79)$ & $70.15(178.11)$ & $82.09(244.57)$ \\
\hline Percentage 20-29 & $17.55(2.06)$ & $17.32(1.81)$ & $16.95(2.01)$ \\
\hline Percentage males & $50.37(1.21)$ & $50.43(1.09)$ & $50.42(1.19)$ \\
\hline Population Density & $111.22(265.68)$ & $112.84(270.38)$ & $114.65(277.55)$ \\
\hline Unemployment & $10.40(4.09)$ & $12.31(4.71)$ & $10.45(3.21)$ \\
\hline Moran I for crime rate & $0.61^{\text {*** }}$ & $0.54^{\star \star *}$ & $0.39^{\text {** }}$ \\
\hline
\end{tabular}

Note. Figures in parentheses are standard deviations. Significance of Moran I indicated by *** $(1 \%)$.

Source: Own elaboration.

The crime rates of the Turkish provinces for 2008 are shown in Figure 1.

Figure 1

Spatial distribution of crime rates (per 10,000 inhabitants) for 2008

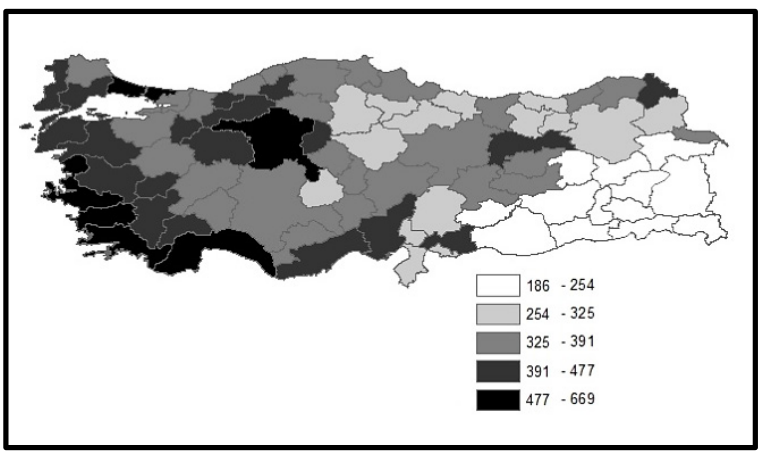

Source: Own elaboration.

It is seen that the highest crime rates are found in the South-west region and South coast of Turkey. These provinces are known to have the highest urbanisation rates. Likewise, the young age population and the education level are also very high in these regions as in the capitol area. Besides, there are large migration rates to the cities of these areas. On the other hand, there are strong traditional family structures in the South-East, East and Central Anatolian regions. Furthermore, the cultural and religious characteristics of these areas are protected and binding, and agricultural activities and animal breeding are the essential economic activities in these regions. 


\section{RESULTS}

The empirical estimation of a baseline pooled ordinary least square (OLS) model (i.e., unadjusted for intra-regional correlation, inter-temporal heterogeneity and spatial spillover) is provided by the second column of Table 5. The third column of Table 5 reports results for the SAC-SUR model (i.e., adjusted for intra-regional correlation, inter-temporal heterogeneity and spatial spillover), while finally an instrumented SAC-SUR (i.e. adjusted for endogeneity between risk of deterrence and crime rate by using lagged crime rates as instrument for risk of deterrence) appears in the fourth column. Throughout, all variables (except the constant term and the time trend) enter estimation in log transforms. Significant indication is provided of inter-temporal heterogeneity (i.e. the LR test for SUR versus OLS) as well as of spatial spillover (i.e. the LR test for SAC-SUR versus SUR). The instrumentalised SAC-SUR does not nest the other specifications and thus does not facilitate LR specification tests. However, the LogL, AIC and R-Square values strongly support the instrumentalised specification. Thus, given the counter-intuitive positive coefficient for the instrumentalised risk of deterrence, and for matter of completeness, potential effects of the explanatory variables will be discussed in light of all three specifications.

Turning to the a detailed examination of the estimated effects of the explanatory variables, all columns of Table 5 point to a positive time trend in the crime rates which indicates that the crime rate increases with approximately 5-9 percent per year. Further, the evidence regarding varying risk profiles across certain population segments is provided. A positive relationship between percentage of males and crime rates is consistently reported and indicates a potential causal effect of the former on the latter. Thus, policy initiatives directed toward areas with an excess of male inhabitants is something that should be considered for the case of Turkey. Poverty seems not to be related to level of criminal activity. This conflicts the arguments of Ehrlich (1973) and Entorf and Spengler (2000) who pointed out that income may be a proxy for illegal income opportunity, while it partly can be seen as a support for the argument of Trumbull (1989) that high incomes should provide more opportunities for engaging in legal activities. For the present case, a potential policy implication should be that stimulating wage increases is not a particularly important initiative. Rather, other aspects of social capital are more important target variables for policy initiatives. Thus, unemployment is, as expected and in accordance with the arguments and outcomes of previous studies (Entorf and Spengler, 2000; Small and Lewis, 1996; Papps and Winkelman, 1998; Lauridsen, 2009 and 2010; Lauridsen et al., 2013), positively related to crime rates, i.e., an increase in unemployment leads to a fall in the opportunity cost of criminal activity. Percentage of males appears to be positively related to crime rate as in previous studies 
(Lauridsen 2010), which indicates that policy initiatives might be targeted toward regions with an excess of male population. On the other hand, education appears less connected to crime rates opposed to previous studies (Lauridsen et al., 2013). Eventually, the positive sign of the relationship may indicate endogeneity problems, i.e. regions with high economic activities and high education are more attractive for criminals. Next, a counter-intuitive negative relationship between percentage of youngsters and crime rates is reported. Potentially, this may express a proxy relationship, i.e. that regions with activities attractive for youngsters simultaneously stimulate these to stay longer in the region and refrain from criminal activities. Further, crime rates do not seem to be higher in regions on the border line. Finally, a strong positive spatial spillover is reported similar to what is reported by other recent studies (Lauridsen, 2010; Lauridsen et al., 2013). This spillover appears less affected by potential endogeneity problems, as the magnitude and significance level of the autocorrelation coefficient remain stable across specifications. Thus, in extension of intra-regional policy initiatives aiming at reducing criminal activities, crossregional coordination and initiatives should also be considered.

Table 5

Estimated models for crime rate

\begin{tabular}{|c|c|c|c|}
\hline Variable & OLS & SAC-SUR & SAC-SUR (instrumentalised) \\
\hline Constant & $-8.20(-2.38)^{\star \star}$ & $0.27(0.07)$ & $-0.05(-0.04)$ \\
\hline Time trend & $0.07(4.69)^{\star \star \star}$ & $0.09(6.85)^{\star \star \star}$ & $0.05(4.57)^{\star \star \star *}$ \\
\hline Risk of deterrence & $0.19(7.95)^{\star \star * *}$ & $0.02(1.14)$ & $0.67(40.15)^{* \star *}$ \\
\hline Poverty & $-0.04(-0.31)$ & $-0.07(-0.85)$ & $-0.04(-0.69)$ \\
\hline Education & $0.06(3.38)^{\star \star *}$ & $0.04(2.09)^{\star *}$ & $0.01(0.82)$ \\
\hline Percentage 20-29 & $-0.90(.4 .27)^{* * *}$ & $-0.61(-2.20)^{\star *}$ & $-0.27(-3.21)^{\star \star \star}$ \\
\hline Percentage males & $4.02(4.10)^{\star \star \star}$ & $1.78(1.50)$ & $1.28(3.41)^{\star \star \star}$ \\
\hline Population Density & $0.04(2.48)^{\star *}$ & $0.01(0.33)$ & $-0.001(-0.08)$ \\
\hline Unemployment & $0.02(0.68)$ & $0.05(1.88)^{*}$ & $0.03(2.07)^{\star *}$ \\
\hline Georgia & $0.05(0.71)$ & $0.08(0.65)$ & $0.03(1.28)$ \\
\hline Armenia & $0.11(1.36)$ & $0.12(0.88)$ & $0.05(1.50)$ \\
\hline Iran & $-0.14(-2.33)^{\star \star}$ & $-0.08(-0.84)$ & $-0.01(-0.40)$ \\
\hline Iraq & $0.02(0.19)$ & $0.01(0.11)$ & $-0.01(-0.21)$ \\
\hline Syria & $-0.08(-1.76)^{\star}$ & $-0.06(-0.69)$ & $0.03(1.73)^{*}$ \\
\hline Greece & $0.07(0.53)$ & $0.30(1.62)$ & $0.08(1.87)^{*}$ \\
\hline Bulgaria & $-0.08(-0.89)$ & $-0.19(-1.18)$ & $-0.08(-2.34)^{\star *}$ \\
\hline Spatial spillover $(\lambda)$ & NA & $0.45(3.95)^{\star * *}$ & $0.43(3.72)^{\star * *}$ \\
\hline Number of observations & 243 & 243 & 243 \\
\hline R-Square & 0.56 & 0.38 & 0.89 \\
\hline LogL & 433.94 & 545.47 & 516.95 \\
\hline AIC & -592.34 & -844.94 & -987.90 \\
\hline LR (SUR vs. OLS) & $138.02^{\star \star \star}$ & & \\
\hline LR (SAC-SUR vs. SUR) & & $85.04^{* * *}$ & \\
\hline
\end{tabular}

Note: $T$-values in parentheses. Significance indicated by ${ }^{* \star *}(1 \%),{ }^{* *}(5 \%)$, and ${ }^{*}(10 \%)$. For SUR (model not reported) LogL $=502.95$ and $A / C=-821.88$.

Source: Own elaboration. 


\section{CONCLUSIONS}

The study does not support that crime in Turkey is governed by economic rationality, as the propensity to commit criminal activities appears positively related to the risk of deterrence. However, this does not preclude that local efforts to increase the rate of deterrence may pay off, as the persistently positive relationship may be due to insufficiency of the instruments chosen.

Potential presence of higher risk profiles for certain population segments is shown. These profiles correspond to some extent to what is obtained by previous empirical studies based on European data. Specifically, although it should be kept in mind that our results formally only prove interrelationships and not causal effects, our results support the interpretation thaturbanisation, high proportions of young people and high unemployment rates are driving forces for criminal activity. Thus, from a regional policy perspective, initiatives aiming to reduce unemployment are worth considering. Likewise, policy initiatives and campaigns aiming to reduce criminal activities in urban areas and among youngsters may pay off. On the other hand, crime rates seem to be less related to educational attainment, percentages of foreigners and percentages of males. Thus, these population segments do not seem to be the most obvious target groups for policy initiatives.

Next, turning focus to policy recommendations aiming at reducing crime rates in Turkey, income inequality should be prevented. Population growth rate should be reduced, and job opportunities in underdeveloped regions should be improved by targeted regional development policies adopted for preventing rural depopulation. The legislations governing scope of criminal offences should be improved, and insufficiency in applying criminal sanctions should be eliminated. In other words, laws should potentially be more deterrent. In conclusion, the high amount of illicit money one can earn from criminal activities in Turkey is one of the leading reasons why individuals turn into crime. Thus, a policy depriving criminals from illicit money should be adopted.

Finally, potential presences of spatial spillover patterns in criminal activity are shown to be relevant aspects. From a regional policy perspective, this implies that while initiatives and policies directed toward criminal activities may well be formulated on a regional level, coordination across regional borders of such an effort would be highly recommendable.

\section{REFERENCES}

AASNESS, J.; EIDE, E. and SKJERPEN, T. (1994). "Criminometrics, latent variables, panel data and different types of crime". Discussion Paper, No. 124. Oslo: Statistics Norway. 
ANSELIN, L. (1988). Spatial econometrics: Methods and models. Amsterdam: NorthHolland.

AVIO, K.L. and CLARKE, C.S. (1976). Property crime in Canada: an econometric study. Ontario: Council of Economic Research.

BALLER, R.; ANSELIN, L.; MESSNER, S.; DEANE, G. and HAWKINS, D. (2001). "Structural covariates of US county homicides rates. Incorporating spatial effects". Criminology 39, pp. 201-232.

BALTAGI, B. (2006). "Estimating an economic model of crime using panel data from North Carolina". Journal of Applied Econometrics, 21, pp. 543-547.

BECKER, G.S. (1968). "Crime and punishment: An economic approach". Journal of Political Economy, 76, pp.169-217.

BODMAN, P.M. and MAULTBY, C. (1999). "Crime, punishment and deterrence in Australia". International Journal of Socio Economics, 24, pp. 884-901.

BUONANNO, P.; MONTOLIO, D. and VANIN P. (2006). "Does social capital reduce crime?". Working Paper 0605, University of Bergamo, Department of Economics.

BREUSCH, T. and PAGAN, A. (1980). "The Lagrange multiplier test and its applications to model specification in econometrics". Rev Econ Stud, 47, pp.239-254.

BRITT, B. and CHESTER, L. (1994). "Crime and Unemployment Among Youths in the United States, 1958-1990: A Time Series Analysis". American Journal of Economics and Sociology, 531, pp. 99-109.

BUONANNO, P. and LEONIDA L. (2006). "Education and crime: Evidence from Italian regions". Applied Economics Letters, 13, pp. 709-713.

BUTCHER, K.F. and PIEHL, A.M. (1998). "Cross-city evidence on the relationship between immigration and crime". Journal of Policy Analysis and Management, 17, pp. 457-493.

BUTTNER, T. and SPENGLER, H. (2003). Local determinants of crime: Distinguishing between resident and non resident offenders. ZEW Discussion Paper No. 03-13.

CAR-HILL, R.A. and STERN, N.H. (1973). "An economic model of the supply and control of recorded offences in England and Wales". Journal of Public Economics, 1, pp. 365-378.

COHEN, J. and TITA, G. (1999). "Diffusion in homicide: Exploring a general method for detecting spatial diffusion processes". Journal of Quantitative Criminology, 15, pp. 491-453.

CORMAN, H. and MOCAN, H.N. (2000). "A time series analysis of crime deterrence and drug abuse in the New York city". American Economic Review, 90, pp. 584-604.

CORNWELL, C. and TRUMBUL, W. I. (1994). "Estimating the economic model of crime with panel data". Review of Economics and Statistics, 76, pp. 360-366.

CROALL, H. (1998). Crime and Society in Britain. London: Longman.

DILULIO, J. (1996). "Help wanted: Economists, crime and public policy". Journal of Economic Perspectives, 10, pp. 3-24.

EDMARK, K. (2005). "Unemployment and crime: is there a connection?". Scandinavian Journal of Economics, 107, pp. 353-373.

EHRLICH, I. (1973). "Participation in illegitimate activities: A theoretical and empirical investigation”. Journal of Political Economy, 81, pp. 521-567. 
EIDE, E. (2000). Economics of Criminal Behavior. In B. Bouckaert B. and G. de Geest (eds.). Encyklopedia of Law and Economics, Vol. V, pp. 345-89. Cheltenham: Edward Elgar.

ENTORF, H. and SPENGLER, H. (2000). "Socioeconomic and demographic factors of crime in Germany: Evidence from panel data of German states". International Review of Law and Economics, 20, pp. 75-106.

ENTORF, H. and WINKEr, P. (2001). "The economics of crime: Investigating the drugscrime channel. Empirical evidence from the panel data of the German states". Working paper, No. 2, International University of Germany, Brussel.

ENTORF, H. and WINKER, P. (2008). "Investigating the drugs-crime channel in Economics of Crime Models: Empirical evidence from panel data of the German states". International Review of Law and Economics, 28, pp. 8-22.

FAJNZYLBER, P.; LEDERMAN, D. and LOAYZA, N. (2002). "Inequality and violent crime". Journal of Law and Economics, 45, pp. 1-40.

HANSEN, K. and MACHIN, S. (2003). "Spatial Crime Patterns and the Introduction of the UK Minimum Wage". Oxford Bulletin of Economics and Statistics, 64, pp. 677-697.

LAURIDSEN, J. (2009). "Is Baltic crime economically rational?". Baltic Journal of Economics, 9, pp. 31-38.

LAURIDSEN, J. (2010). "Is Polish crime economically rational?". Journal of Regional Analysis and Policy, 40 , pp. 125-131.

LAURIDSEN, J.; NANNERUP, N. and SKAK, M. (2013). How is Owner-Occupied Housing Related to Crime?. Working paper, Department of Business and Economics, University of Southern Denmark.

LEVITT, S. (1996). "The effect of prison population size on crime rates: Evidence from prison overcrowding litigation". Quarterly Journal of Economics, pp. 319-333.

LEVITT, S. (1997). "Using electoral cycles in police hiring to estimate the effect of the police on crime". American Economic Review, 87, pp. 270-290.

LEVITT, S. (1998). "Why do increased arrest rates appear to reduce crime: Deterrence, incapacitation or measurement error". Economic Inquiry, 36, pp. 353-372.

LÓPEZ, F.A.; MATILLA, M.; MUR, J. and RUIZ, M. (2011). "Four Tests of Independence in spatio-temporal data". Papers Regional Science, 90(3), pp. 663-685.

MARSELLI, R. and VANNINI, M. (1997). "Estimating a crime equation in the presence of organized crime: Evidence from Italy". International Review of Law and Economics, 17, pp. 89-113.

MESSNER, S. and ANSELIN, L. (2002). Spatial Analysis of homicide with area data. Mimeo. Urban-Champaign: University of Illinois.

MIRON, J. (2001). "Violence, guns, and drugs: A cross country analysis". Journal of Law and Economics, 44, pp. 615-633.

MOCAN, N. and REES, D.I. (1999). Economic conditions, deterrence and juvenile crime: Evidence from micro data. NBER Working Paper No. 7405, Cambridge, MA.

MUR, J.; LÓPEZ, F.A. and HERRERA, M. (2010). "Testing for spatial effect in Seemingly Unrelated Regressions". Spatial Economic Analysis, 5(4),pp. 399-440.

PAPPS, K. and WINKELMAN, R. (1998). Unemployment and crime: New answers to an old question. Discussion Paper No. 25, IZA, Bonn.

PUECH, F. (2004). How do criminals locate?. Crime and spatial dependence in Minas Gerais. Mimeo. Cerdi: Auvergne University. 
SANDELIN, B. and SKOGH, G. (1986). "Property crimes and the police: An empirical analysis of Swedish municipalities". Scandinavian Journal of Economics, 88, pp. 547561.

SMALL, J. and LEWIS, C. (1996). Economic crime in New Zealand: Causation or coincidence? Working Paper No. 158, University of Auckland.

TRUMBULL, W. (1989). "Estimations of the economic model of crime using aggregate and individual level data". Southern Economic Journal, 56, pp. 432-439.

WAHLROOS, B. (1981). "On Finnish property criminality: An empirical analysis of the post-war era using Ehrlich model". Scandinavian Journal of Economics, 83, pp. 553562.

WHITHERS, G. (1984). "Crime and punishment and deterrence in Australia: An empirical investigation". Economics Records, 60, pp.176-185.

WITTE, A.D. (2002). "Crime causation: Economic theories". In J. Dressler (ed.) Encyclopedia of Crime and Justice, Vol 1, pp. 302-308. New York: MacMillan.

WOLPIN, K.I. (1978). "An economic analysis of crime and punishment in England and Wales". Journal of Political Economy, 86, pp. 815-840.

ZELLNER, A. (1962). "An Efficient Method of Estimating Seemingly Unrelated Regressions and Tests of Aggregation Bias". Journal of the American Statistical Association, 58, pp. 977-992. 